\title{
Bone Epithelioid Hemangioendothelioma
}

National Cancer Institute

\section{Source}

National Cancer Institute. Bone Epithelioid Hemangioendothelioma. NCI Thesaurus.

Code C121941.

A low-grade malignant blood vessel neoplasm arising from the bone. It is characterized by the presence of epithelioid endothelial cells. The neoplastic cells are arranged in cords and nests, which are embedded in a myxoid to hyalinized stroma. 